\title{
R.D. Laing's The Divided Self: An Existential Study of Sanity and Madness (1965)
}

lain Ferguson, University of the West of Scotland

In its February issue this year, the London Review of Books carried a review of Hidden Valley Road: The Mind of an American Family by Robert Kolker (Friedell, 2021). The book is a study of the Galvins of Colorado Springs, apparently described by one doctor as "the most mentally ill family in America". Of the 12 children born to Don and Mimi Galvin between 1945 and 1965, five were later diagnosed with schizophrenia. A sixth seemed well enough until, aged 22, he shot and killed his girlfriend and then himselfbefore he had been given any diagnosis. Kolker's book explores the family's history, reviews a range of theories about the nature of "schizophrenia" (more on the inverted commas below) and ends by pointing optimistically to an experiment now under way of giving pregnant women high doses of choline, a nutrient found in eggs which, apparently, is essential to foetal "brain scaffolding".

Lack of choline may, or may not, have been a contributory factor to the dreadful mental distress experienced by the Galvin children. What some may see as more pertinent, however, is the disclosure by Donald, the oldest child, to his mother a few years before his first psychotic breakdown that he and some of the other children had been sexually abused by a priest who regularly visited the house.

AOTEAROA NEW ZEALAND SOCIAL WORK 33(2), 56-60.

CORRESPONDENCE TO: lain Ferguson

iainferguson1917@gmail.com
Debates over the causes, nature and treatment of the condition designated "schizophrenia" by the Swiss psychiatrist, Eugen Bleuler, in 1908 have raged since it was first identified some year earlier by Bleuler's German counterpart and the founder of modern biomedical psychiatry, Emil Kraepelin. Kraepelin believed that what he was observing was a form of brain disease which particularly affected young people, "a precocious madness", and had called it dementia praecox. However, it was Bleuler's re-branding which won out. Since then, "schizophrenia" (and, in this review, I am following the example of the writer and former mental health nurse Nathan Filer in using inverted commas to keep us mindful that there exist alternative narratives; Filer, 2019) has been seen as the epitome of "severe mental illness" or "madness". For most of that time, hegemony over both the understanding and the treatment of the condition has been exercised almost exclusively by the psychiatric profession. Other professions, such as social work or clinical psychology, may be seen to have some contribution to make towards the amelioration of "less serious" forms of mental distress such as anxiety and depression (though the trend in recent decades has been in the opposite direction and towards the increasing medicalisation of all forms of mental distress, including grief and bereavement). But "schizophrenia", with its characteristic "positive" symptoms of visual or auditory hallucinations and delusional ideas and "negative" symptoms such as lack of motivation and emotional flatness has been the psychiatric specialism par excellence. So it is perhaps not surprising that it was this condition which should have drawn the attention, and subsequently became the life work of one indisputably precocious young Scottish psychiatrist in the 1950s, Ronald David Laing, and the subject of his first book, The Divided Self: an 
Existential Study of Sanity and Madness (Laing, 1965).

Laing was born in 1927 in Govanhill, a respectable working-class suburb on the South Side of Glasgow (this biographical section draws on an earlier publication, Ferguson, 2017). His father worked as an electrical engineer with Glasgow Corporation, his mother, like most women at the time, was a housewife. Laing was a bright boy who attended a local feepaying grammar school. According to his own account in the book Mad to be Normal, based on conversations with Bob Mullan, he spent a huge amount of time in his late teens in the local public library which seems to have had a particularly good European philosophy section (Mullan, 1995). There he read Nietzsche, Kierkegaard, Sartre and other existentialist philosophers. As a medical student at Glasgow University in the late 1940s, he broadened his reading to include Marx and Lenin and began what he called his "first literary project" which was to write a biography of the great Scottish revolutionary socialist, John McLean (sadly, never completed).

This was the period of National Service in the UK when all young men were required to spend time in the army and on graduating from Glasgow University in the early 1950s, Laing joined the Royal Army Medical Corps and was sent to a British Army Psychiatric Unit at Netley in Hampshire. Netley seems to have been a particularly grim place, but it confirmed Laing in his intention to become a psychiatrist. After leaving the army, he took up a post at Gartnavel Royal Hospital in Glasgow before becoming a senior registrar in Glasgow University Department of Psychiatry at the Southern General in 1955.

In Mad to be Normal, Laing gives a flavour of the treatments on offer within psychiatric hospitals as he found them at this time. Insulin coma was the standard practice everywhere with electric shocks sometimes being given in the middle of the coma. Both in the army and at Gartnavel, the range of treatments ranged from the pre-tranquillizers of paraldehyde and barbiturates and bromides to electric shocks and insulin and lobotomy.

At this time, as a young psychiatrist, Laing was involved in all of these practices, but was beginning to have doubts. In his autobiography Wisdom, Madness and Folly, he later wrote:

I was just beginning to suspect that insulin and electric shocks did more harm than good. In fact I had begun to question my own sanity, because I was beginning to suspect that insulin and electric shocks, not to mention lobotomy and the whole environment of a psychiatric unit, were ways of destroying people and driving people crazy if they were not so before and crazier if they were. But I had to put it to myself - maybe I was completely mistaken. How could the whole of psychiatry be doing the opposite of what I assumed psychiatry was about treating, curing if possible, arresting the course of mental illness? (Laing, 1985, p. 106)

Laing's first attempt to address these concerns and articulate an alternative way of understanding "schizophrenia" came in The Divided Self, originally published in 1965, but written some years earlier and based on his experiences in Netley and in Gartnavel. As he himself noted in a later self-criticism, the book does not represent a complete break with the then dominant ways of understanding severe mental disorders. So, for example, in contrast to his later work, he still talks of "schizophrenia" as a distinct psychiatric condition. In addition, written while he was working at the Tavistock Clinic, the home of British psychoanalysis, the book shows the influence of more senior colleagues such as Donald Winnicott, for example in the distinction Laing makes between the "true" self and the "false" self. In one key respect, however-its grounding in existentialism — the book was highly unusual in a psychiatric world dominated 
by biomedical psychiatry on the one hand and varieties of Freudianism on the other. As Peter Sedgwick, one of Laing's most perceptive critics, noted:

One of the most difficult of philosophies was brought to bear on one of the most baffling of mental health conditions, in a manner which, somewhat surprisingly, helped to elucidate both. Existential philosophy, with its reputation of introverted cloudiness and speculative indiscipline, was here set working in a concrete, practical and socially urgent context-the understanding of the mentally ill. Conversely, a major form of psychosis was elucidated as a mental system possessing lawful shape and sequence, comprehensible in existential terms as the outcome of rational strategies adopted by the patient in the face of an ambiguous and threatening personal environment. (Sedgwick, 1982, p. 74)

That existentialist framework shaped Laing's main concern in the book, which was to understand the experience of being schizophrenic. What does it feel like? How can we get inside the mind of someone with this condition? How can we make sense of it?

A major barrier in the way of doing so, he argued, was a psychiatric language which viewed people labelled as schizophrenic not as whole human beings but as machines, as disembodied brains (or in our own time, as bundles of genes). Anticipating Michel Foucault's concept of the clinical gaze, he argued:

As a psychiatrist, I run into a major difficulty at the outset: how can I go straight to my patients if the psychiatric words at my disposal keep the patient at a distance from me? How can one demonstrate the general human relevance and significance of the patient's condition if the words one has to use are specifically designed to isolate and circumscribe the meaning of the patient's life to a particular clinical entity? (Laing, 1965 , p. 18)

Bleuler had once commented that, when all was said and done, the patients he was seeing were as strange to him as the birds in his garden. By contrast, Laing followed the American psychoanalyst, Harry Stack Sullivan, in arguing that "the psychotic" is more than anything else, "simply human". Connecting with that humanity, however, required the creation of a new science of persons, a way of understanding and relating to patients not as brains or objects but as human beings, with feelings, hopes and desires. And the key purpose of that science, Laing argued, was to render the speech of people diagnosed as schizophrenic intelligible - to show, in other words, that it had a meaning, rooted in past or present life experience, and was not simply the product of a diseased brain, as the dominant biomedical psychiatry would have it. So, for example, when, in a case study entitled "The Ghost of the Weed Garden', Julie, a young woman with a diagnosis of schizophrenia, talks about not being a person, being unreal and says that "a child has been murdered", Laing suggests she was describing not a literal but an existential truth, the possible origins of which he explores in the case study. And, he argued, that process of making intelligible the experience of Julie, and others similarly diagnosed, was not just an intellectual activity. It also involved "love" or what would probably be called today "empathic understanding", a quality or skill he sought to deploy while working at Gartnavel, including spend hours sitting in padded cells with catatonic patients regarded as incurable.

His experience of working with such patients led Laing to conclude that, at the root of much of what is called "schizophrenia" was what he labelled "ontological insecurity". People described as schizophrenic seemed to lack a sense of themselves as alive and real and separate from other people and therefore had to find ways to maintain boundaries to protect their sense of identity-defences 
that were then seen as the symptoms of schizophrenia. That strategy or response, he suggested in what he described as the central thesis of the book, was "a possible outcome of a more than unusual difficulty in being a whole person with the other and with not sharing the common-sense (i.e. the community sense) way of experiencing oneself in the world". In other words, there was a mismatch between the experiences and perceptions of the young child or adolescent and the denial and/or distortions of these experiences and perceptions of her caregivers. In Sanity, Madness and the Family, published in 1964, Laing and his colleague Aaron Esterson would identify the "double bind", where a family member is presented with irreconcilable demands, as a key mechanism in this process (Laing \& Esterson, 1970). The classic example of a negative double bind is of a mother telling her child that she loves them, while at the same time turning away in disgust, or inflicting corporal punishment: the words are socially acceptable; the body language is in conflict with it. That was later, however, and in The Divided Self, he confines himself to calling for more research into family dynamics and the possibility of what he calls "schizophrenegenic families".

The central idea of The Divided Self-that madness might be intelligible-fitted well with other challenges to traditional psychiatric thinking that came out soon after, such as Michel Foucault's Madness and Civilisation (Foucault, 1964) and Erving Goffman's Asylums (Goffman, 1968) and, unusually for a psychiatric text, by the mid1960s the book had become a best seller. By then, however Laing's thought had moved on. In a Preface to the Pelican edition of the book in 1964, four years after the initial publication, he commented:

One cannot say everything at once. I wrote this book when I was twenty eight. I wanted to convey above all that it was more possible than is generally supposed to understand people diagnosed as psychotic. Although this entailed understanding the social context, especially the power situation within the family, today I feel that, even in focusing upon and attempting to delineate a certain type of schizoid existence, I was already partially falling into the trap I was seeking to avoid. I am still writing in this book too much about Them, and too little of us. (Laing, 1964, p. 11)

As this suggests (and as I have explored at greater length elsewhere: Ferguson, 2017), Laing's thought was moving in an increasingly political direction. In 1967, with his fellow psychiatrist, David Cooper, he was the organiser of the Dialectics of Liberation Conference in London, an astonishing event which explored alternatives to capitalism and brought together on one platform many of the leading lights of the 1960s' New Left, including the Frankfurt School philosopher, Herbert Marcuse, and the Black Panther leader, Stokely Carmichael. By this time Laing had himself become something of a cult figure on the Left, reflected in the huge popularity of books like The Politics of Experience, a collection of essays which showed his growing politicisation (Laing, 1967).

What that book and his subsequent books also evidenced, however, was his increasing attraction to mysticism, an attraction which ultimately over-shadowed any political involvement or analysis and which was the object of a biting critique by the political philosopher and activist, Peter Sedgwick.

The ascendancy of the New Right in the 1980s, spearheaded by the election of Margaret Thatcher as Prime Minister in the UK and Ronald Reagan as President in the USA, coupled with the return of an increasingly assertive biomedical psychiatry, led to a savage assault on the ideas of "antipsychiatry" (a term, incidentally, which Laing himself rejected) and also to the demonisation of Laing himself (a task made easier, it has to be said, both by his growing tendency to turn up drunk at public lectures and interviews and by his adoption of 
increasingly wacky ideas and practices, such as organising mass "re-birthing" sessions on Wimbledon Common).

Some sixty years on since the publication of The Divided Self, it is now clear that Laing's focus on the schizophrenegenic family as a complete explanation of psychotic breakdown was both too narrow and too open to the possibility of parent-blaming. For many people, of course, it remains true that, in Philip Larkin's much-quoted words, "they fuck you, up your mum and dad" (even if, as he suggests in the next line, "they may not mean to but they do"). However, as research in recent decades into the impact of trauma on mental health has shown, so do lots of other things, including child abuse, bullying and racism. So we should read this book and Laing's later work critically. Having said that, for those of us today, mental health workers of whatever sort, who wish to develop a practice based on an understanding that the distressed people whom we are seeking to help are "simply human" and that the roots of their distress will often lie in their life experiences in an oppressive and exploitative society rather than in their brains or genes, then The Divided Self remains an indispensable starting point.

\section{References}

Ferguson, I. (2017). Making sense of madness: Revisiting R D. Laing. Critical and Radical Social Work, 6(1), 67-76. https://doi.org/10.1332/204986018X15199226335060

Ferguson, I. (2017). Politics of the mind: Marxism and mental distress. Bookmarks.

Filer, N. (2019). The heartland: Finding and losing schizophrenia. Faber and Faber.

Friedell, D. (2021). A pie every night. London Review of Books, 43(4). https://www.Irb.co.uk/the-paper/v43/n04/ deborah-friedell/a-pie-every-night

Foucault, M. (1964). Madness and civilisation. Penguin Random House

Goffman, E. (1968). Asylums: Essay on the social situation of mental patients and other inmates. Penguin.

Laing, R. D. (1965). The divided self: An existential study of sanity and madness. Pelican Edition.

Laing, R. D. (1967). The politics of experience and the bird of paradise. Penguin.

Laing, R. D. (1985). Wisdom, madness and folly: The making of a psychiatrist, 1937-57. Canongate.

Laing, R. D., \& Esterson, A. (1970). Sanity, madness and the family. Pelican.
Mullan, B. (1995). Mad to be normal: Conversations with R. D. Laing. Free Association Books.

Sedgwick, P. (1982). Psychopolitics. Pluto Press. 